\title{
Application of Crude Protease from Cheap and Local Raw Material as a Biopesticide for the Disruption of Pomacea Canaliculata Eggs
}

\author{
Noor Hasyierah Mohd Salleh and Dachyar Arbain
}

\begin{abstract}
The application of crude protease of Aspergillus oryzae to suppress the hatchability of Pomacea canaliculata eggs is highlighted. The enzyme was produced through solid state fermentation (SSF) using cassava, which is cheap and abundantly available. It was found that the enzyme suppressed the hatchability of $P$. canaliculata eggs as much as $30 \%$ and $20 \%$ at $20.8 \mathrm{U} / \mathrm{ml}$ enzyme for 3 and 9 days old eggs respectively. The ANOVA result revealed that the hatchability was significantly affected by both protease concentration as well as egg's age. The $\mathrm{LC}_{50}$ for 3 and 9 days old eggs were $3.29 \mathrm{U} / \mathrm{ml}$ and $3.54 \mathrm{U} / \mathrm{ml}$, respectively; while $L C_{95}$ for 3 and 9 days old eggs were $19.11 \mathrm{U} / \mathrm{ml}$ and $20.09 \mathrm{U} / \mathrm{ml}$ respectively. It is proposed that the crude protease propagated from SSF using locally available and cheap material should be considered as an alternative biopesticide to suppress the hatchability of $P$. canaliculata eggs.
\end{abstract}

Index Terms-Aspergillus oryzae, pomacea canaliculata, hatchability, eggs.

\section{INTRODUCTION}

The application of an enzyme as a biopesticide against several pests has been reported previously [1]. It offers advantages over chemical pesticides, even though its action may not be as fast as chemical pesticides. Ideally, enzyme-based biopesticide should be less toxic to the user and non-targeting organisms. Additionally, it is preferable to have a biopesticide which can be produced locally using cheap local raw materials [2]. Protease, a commercial enzyme belongs to many types of fungus and bacteria theoretically could cleaves the protein and disrupted the main function of protein. Bacillus and Aspergillus are among bacteria and fungus species that are well known to excrete protease [3]-[6]. Aspergillus is widely known for its capability to grow on solid substrate for its physical support and as a source of nutrient [7], [8]. For enzyme-based biopesticide preparation, solid state fermentation (SSF) is preferable over submerged fermentation (SMF) because it does not require sophisticated equipment such as fermenter and it can utilize cheap and locally available raw materials.

Pomacea canaliculata is a freshwater snail that has become a potent pest in paddy field due to its feeding habits towards young stem and leaves of paddy [9]. The vast $P$. canaliculata invasion has prompted researchers and farmers

Manuscript received May 10, 2014; revised July 8, 2014. This work was supported in part by the Malaysian Ministry of Science, Technology and Innovation (MOSTI) under Science Fund Grant (9005-00056).

The authors are with the School of Bioprocess Engineering, University Malaysia Perlis, 02600 Arau, Perlis, Malaysia (e-mail: hasyierah@unimap.edu.my, dachyar@unimap.edu.my). to seek for proper and effective control of this snail [10]. Most of the approaches are aimed at controlling the snail's flesh. However, even though controlling the flesh is important, it is equally important to suppress the hatching of $P$. canaliculata eggs [11]-[14]. It is known that the eggshell generally covered by cuticle layer which consists of $>85 \%$ protein [15] and served as a protection against dehydration and bacterial penetration onto the eggshell [16]-[19]. The application of a commercially available protease has initiated the disruption of this cuticle, thus resulted in the suppression of the hatchability of $P$. canaliculata eggs, has been previously described [20], [21]. In this case, protease might denatured the protein within the cuticle, hence exposed the eggs to harsh environment which consequently affected its hatcability. Despite its efficacy, the use of commercial protease as a biopesticide to suppress the hatchability of P.canaliculata could be too expensive for the farmers, particularly in the developing countries where the invasion of the snail prevails. Therefore, it is deemed necessary to find an alternative source of protease enzyme preferably using cheap and locally available materials through simple propagation method.

\section{MATERIALS AND METHOD}

\section{A. Pomacea Canaliculata Egg Collection}

The fresh eggs of the snails were collected from a nearby riverbank area of paddy field in Perlis, Malaysia and were kept in an open breeding chamber $(62 \mathrm{~cm} \times 40 \mathrm{~cm} \times 46 \mathrm{~cm})$, which was filled with tap water to provide humid condition as was described previously [22] with a slight modification. After 3 and 9 days, the eggs were located in separate containers and the mass of each egg was $0.5 \mathrm{~g}$ for the hatchability studies.

\section{B. Aspergillus Oryzae Propagation}

Aspergillus oryzae was propagated through solid state fermentation method, using tapioca as the carbon source based on the previous report [23] with a slight modification. Briefly, the peeled tapioca was washed thoroughly, and ground before drying overnight in an oven at $50{ }^{\circ} \mathrm{C} .2 \mathrm{~g}$ of the prepared tapioca was placed in a shake flask and mixed well with $50 \mathrm{ml}$ of distilled water and $10 \mathrm{ml}$ of $10 \%$ glucose before autoclaving altogether at the $121 \mathrm{OC}$ for 15 mins. These were prepared in triplicates. $2 \times 10^{6} \mathrm{cfu} / \mathrm{ml}$ of $A$. oryzae was added into the flask aseptically before incubating at $37{ }^{\circ} \mathrm{C}$. Samples which were harvested every $24 \mathrm{hrs}$ were added with $50 \mathrm{ml}$ distilled water before vortexing for 5 mins. The samples were 
then centrifuged at $8000 \mathrm{rpm}$ for 5 mins to separate between the precipitates and the supernatant fluid. The supernatant were then kept for protease assay at $4{ }^{\circ} \mathrm{C}$ while the precipitates were dried overnight at $90{ }^{\circ} \mathrm{C}$ to measure the cell dry weight.

\section{Bacillus sp. Propagations}

Bacillus subtilis media was used to propagate as previously described [24]. Quantitatively (g/l), glucose, 2, casein 0.5 , pepton, 0.5 , yeast extract 0.5 , and $50 \mathrm{ml}$ salt solution $(\mathrm{g} / \mathrm{l}) \mathrm{KH}_{2} \mathrm{PO}_{4} 5, \mathrm{MgSO}_{4} \cdot 7 \mathrm{H}_{2} \mathrm{O}$ 5, and $\mathrm{FeSO}_{4} .7 \mathrm{H}_{2} \mathrm{O}$ 0.1 , pH 7.0 were prepared. The media was autoclaved at 121 ${ }^{\circ} \mathrm{C}$ for 15 mins.

The media for Bacillus thuringiensis was propagated as reported previously [25]. Briefly, the media contained (g/l): $\mathrm{MgSO}_{4} .7 \mathrm{H}_{2} \mathrm{O} 0.5, \mathrm{MnSO}_{4} .7 \mathrm{H}_{2} \mathrm{O} \quad 0.1, \mathrm{FeSO}_{4} .7 \mathrm{H}_{2} \mathrm{O} 0.001$, $\mathrm{CuSO}_{4} .5 \mathrm{H}_{2} \mathrm{O} \quad 0.0005, \mathrm{ZnSO}_{4} .7 \mathrm{H}_{2} \mathrm{O} \quad 0.0005, \mathrm{CaCl}_{2} \quad 0.1$, glucose 10 and pepton 5. Pepton was dissolved in phosphate buffer $0.05 \mathrm{M}, \mathrm{pH}$ 7.2. $\mathrm{CaCl}_{2}$ and glucose was autoclaved separately. The media was autoclaved $121{ }^{\circ} \mathrm{C}$ for 15 mins.

Inoculum of B. thuringiensis and B. subtilis (48 hr old culture) were prepared in nutrient broth and $10 \%$ of the inoculum were added to the sterilized growth media for protease production. Both of the growth media were agitated at $180 \mathrm{rpm}$ at $37^{\circ} \mathrm{C}$. Each sample was prepared in triplicate. Sampling was performed every 60 mins during the lag phase and every 30 mins during the $\log$ and stationary phases. Turbidity of the samples was measured at $600 \mathrm{~nm}$ and the protease produced was assayed respectively.

\section{Protease Assay}

Protease was assayed spectrophotometrically according to K.R. Sugumaran, et al. (2012) [26]. Casein (0.6\%) was used as the substrate. $1 \mathrm{ml}$ of casein was mixed with $200 \mu \mathrm{l}$ of both filtrates before being incubated for $30 \mathrm{~min}$ at $37^{\circ} \mathrm{C}$. The reaction was stopped with the addition of $1 \mathrm{ml}$ of trichloroacetic acid $(0.4 \mathrm{~mol} / \mathrm{l})$ for $30 \mathrm{~min}$ prior to centrifugation to separate the precipitate. $1 \mathrm{ml}$ of the filtrate was mixed with $2.5 \mathrm{ml}$ of $\mathrm{Na}_{2} \mathrm{CO}_{3}(0.6 \mathrm{~mol} / \mathrm{l})$ and $0.5 \mathrm{ml}$ of Folin Ciocalteu and was incubated for $30 \mathrm{~min}$ before measuring the absorbance at $660 \mathrm{~nm}$. One unit of protease activity was defined as the amount of enzyme required to liberate $1 \mu \mathrm{g}$ of tyrosine per minute.

\section{E. Hatchabilities Studies}

From the three types of microbes studied, only one particular microbe was selected for hatchability studies. This was attributed by the maximum production of protease. The protease therefore was prepared in different concentration from $1.027 \mathrm{U} / \mathrm{ml}$ to $20.8 \mathrm{U} / \mathrm{ml}$. The effect of two factors, namely the protease concentration and the egg's age on the hatchability, were studied. As a comparison of the crude protease effect on $P$. canaliculata egg hatchability, commercial protease was used as a control. Protease of Aspergillus oryzae was purchased from Sigma Aldrich (Kuala Lumpur, Malaysia) and was prepared in different concentrations $(0.5-4 \mathrm{U} / \mathrm{ml}) .1 \mathrm{ml}$ of the enzyme solution of either crude or commercial protease was introduced to $0.4 \mathrm{~g}$ of $P$. canaliculata eggs in five replicates. The protease was rinsed a few times onto eggs to ensure it covered the eggs. The treated eggs were then placed in the breeding chamber
$(62 \mathrm{~cm} \times 40 \mathrm{~cm} \times 46 \mathrm{~cm})$ which was previously filled with tap water to provide a humid condition. Their hatchabilities were observed and recorded after 14 days.

\section{RESUlTS AND DisCUSSION}

\section{A. Protease Production from Three Types of Microbes}

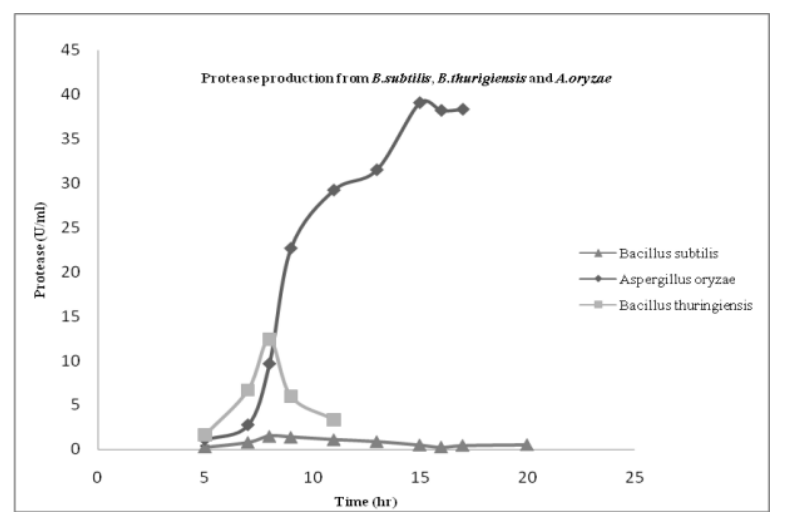

Fig. 1. Protease production from B. subtilis, B. thuringiensis and A. oryzae.

The crude protease production from three types of microbes were assayed (Fig. 1). It was found that Aspergillus oryzae produced relatively higher activity of crude protease (39U/ml) compared to Bacillus subtilis and Bacillus thuringiensis. In fact, the crude protease produced by $A$. oryzae is four times higher than $B$. thuringiensis. Hence, it showed that tapioca which is a local and cheap raw material is a good carbon source to initiate the A. oryzae growth and enhanced the protease production. In this case, it also showed that SSF can produce protease higher than SMF.

\section{B. Effect of Crude Protease Treatment on the Hatchability of 3 (Three) and 9 (Nine) Days Old of P. Canaliculata Eggs}

Based on the result from Fig. 1, the crude protease obtained from tapioca which is a cheap and locally available raw material was used to suppress the hatching of 3 (three) and 9 (nine) days old of $P$. canaliculata eggs. The result is as shown in Fig. 2.



Fig. 2. Effect of crude protease treatment on the hatchability of 3 (three) and 9 (nine) days old of P.canaliculata eggs.

The hatchability of both 3 and 9 days old eggs was reduced when the protease concentration was increased. The hatchability for 9 days old eggs were lower compared to 3 days old eggs for all crude concentration of protease except for the concentration of $1.027 \mathrm{U} / \mathrm{ml}$. At this low crude protease concentration, the hatchability for 9 days old eggs 
were higher than that for 3 days old eggs. This might be due to the fact that the embryo of 9 days old eggs had almost completely developed as indicated by the red-fade color of its shell. In comparison, the color for 3 days old eggs was still reddish.

When the concentrations of crude protease were more than $5.2 \mathrm{U} / \mathrm{ml}$, the hatchability for 3 days old eggs were reduced from $44 \%$ to approximately $30 \%$. A similar observation was recorded in the same range of crude protease concentration, for the 9 days old eggs, where the hatchability was reduced from $34 \%$ to $20 \%$. In this condition, the cuticle and the eggshell of 9 days old eggs were getting thinner preparing for the hatching process which normally occurred on day 12 . Therefore, the high crude protease concentration had efficiently coagulated on the thinning cuticle and well absorbed into the eggshell, thus affected the hatchability of the eggs. It was believed that the A. oryzae also released other enzymes apart from protease such as amylase [23], [27] which therefore reduced the hatchability.

This finding was in a good agreement with a previous report which found that the growth of Paecilomycis lilacinus on the P.canaliculata eggs has successfully stopped the hatching process and the responsible enzyme were identified as lipase, protease, chitinase and amylase [14].

\section{ANOVA Studies}

The ANOVA studies were carried out to investigate the significant factors involved in the hatchability treatment (Table I). It showed that both factors (age and protease concentration) were significantly affected the hatchability based on p-value less than 0.005 .

TABLE I: THE ANOVA STUDIES OF HATCHABILITY USING CRUDE PROTEASE

\begin{tabular}{llll}
\hline \hline Source of variation & $\mathrm{F}$ & $\mathrm{p}$-value & Fcrit \\
\hline Age factor & 145.2863 & $1.26 \mathrm{E}-10$ & 4.351243 \\
Protease concentration & 75.01577 & $9.42 \mathrm{E}-12$ & 2.866081 \\
Interaction & 33.8958 & $1.2 \mathrm{E}-08$ & 2.866081 \\
\hline \hline
\end{tabular}

\section{D. $L C_{50}$ and $L C_{95}$ Studies}

The lethal concentration, $\mathrm{LC}_{50}$ for 3 and 9 days old eggs were $3.29 \mathrm{U} / \mathrm{ml}$ and $3.54 \mathrm{U} / \mathrm{ml}$, respectively, while $\mathrm{LC}_{95}$ for 3 and 9 days old eggs were $19.11 \mathrm{U} / \mathrm{ml}$ and 20.09U/ml (Table II). It showed a linear correlation between protease concentration and the egg's age. The concentration of protease should be high in order to suppress the hatchability since the embryo had already developed completely.

TABLE II: LETHAL CONCENTRATION (LC ${ }_{50}$ AND LC ${ }_{95}$ ) FOR 3 AND 9 DAYS

\begin{tabular}{lll}
\multicolumn{3}{c}{ OLD EGGS } \\
\hline \hline Age & $\mathrm{LC}_{50}$ & $\mathrm{LC}_{95}$ \\
\hline 3 days old & 3.29 & 19.11 \\
9 days old & 3.54 & 20.09 \\
\hline \hline
\end{tabular}

\section{E. Effect of Commercial Protease on the Hatchability of 3} (Three) and 9 (Nine) Days Old of P. Canaliculata Eggs

The effect of commercial protease treatment on the hatchability of 3 (three) and 9 (nine) days old of $P$. canaliculata eggs was investigated as shown in Fig. 3.

It showed that the hatchability was inversely proportionally correlated to the protease concentration.
Apparently, the hatchability trend is similar to that of crude protease hatchability studies as shown in Fig. 3. At low protease concentrations $(2.5-5 \mathrm{U} / \mathrm{ml})$, the hatchability for 9 days old eggs were higher compared to 3 days old eggs. In this condition, the development of the embryo for 9 days old eggs had almost completed. Therefore, they hatched regardless of cuticle alteration compared to the 3 days old eggs which the cuticle were still immatured. However, at high concentration of crude protease $(7.5-10 \mathrm{U} / \mathrm{ml})$ the hatchability became saturated for both 3 and 9 days old eggs. It seemed that, although the embryo development were almost complete, there was a possibility that the enzyme had successfully penetrated through the eggshell and digested the proteinaceous yolk so as to disrupt further embryo development.

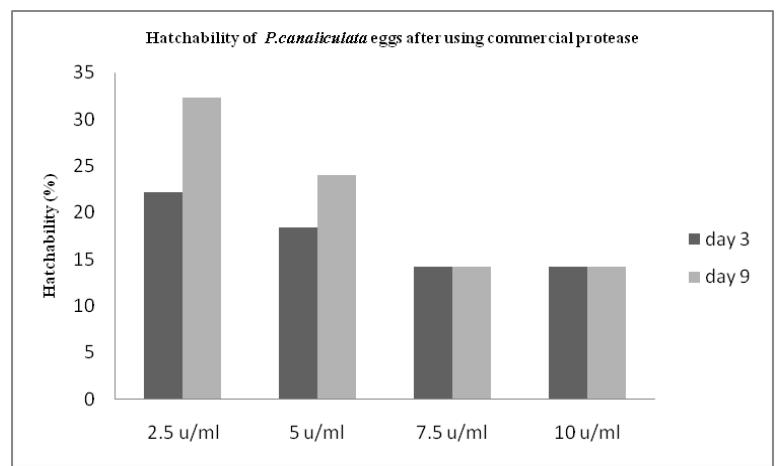

Fig. 3. Effect of commercial protease treatment on the hatchability of 3 (three) and 9 (nine) days old of P.canaliculata eggs.

\section{CONCLUSION}

The present studies showed that $A$. oryzae which was propagated through SSF using locally available and cheap raw material had excreted extracellular protease of higher activity compared to that excreted by $B$. subtilis and $B$. thuringiensis which were both propagated through SMF. It was also showed that the crude protease from A. oryzae at the concentration of $20.8 \mathrm{U} / \mathrm{ml}$ had successfully suppressed the hatchability of $P$. canaliculata eggs as much as $30 \%$ and $20 \%$ for 3 and 9 days old eggs respectively. It can be concluded that protease produced from $A$. oryzae through SSF using locally available raw materials is a good candidate for biopesticide application to suppress the $P$. canaliculata eggs.

\section{ACKNOWLEDGMENT}

The authors thank the School of Bioprocess Engineering, University Malaysia Perlis in providing the facilities to conduct the research work.

\section{REFERENCES}

[1] E. S. A. El-Sheikh and M. D. Mamatha, "The role of alpha and beta hydrolase fold enzyme as biopesticide on pest management," JBiopest, pp. 233-238, 2012

[2] C. Cao, S. Park, and B. B. McSpadden. (2010). Biopesticide control of plant disease: Resources and Products for organic farmers in Ohio. [Online]. http://www.ohioline.osu.edu/sag-factsheet/pdf/0028.pdf. Available:

[3] S. Puri, Q. K. Beg, and R. Gupta, "Optimization of alkaline protease production from Bacillus sp. by response surface methodology," Current Microbiology, vol. 44, pp. 286-290, 2002.

[4] M. A. Longo, I. S. Novella, L. A. Garcia, and M. Diaz, "Comparison of Bacillus subtilis and Serratia marcescens as protease producers under 
different operating conditions," Journal of Bioscience and Bioengineering, vol. 88, pp. 35-40, 1999.

[5] Q. Li, L. Yi, P. Marek, and B. L. Iverson, "Commercial proteases: present and future," FEBS Letter, vol. 587, pp. 1155-1163, 2013.

[6] P. R. Lomate and V. K. Hivrale, "Effect of Bacillus thuringiensis (Bt) Cry1Ac toxin and protease inhibitor on growth and development of Helicoverpa armigera (Hubner)," Pesticide Biochemistry and Physiology, vol. 105, pp. 77-83, 2013.

[7] A. Pandy, "Solid state fermentation," Biochemical Engineering Journal, vol. 13, pp. 81-84, 2003.

[8] S. Sivaramakrishnan, D. Gangadharan, K. M. Namphothiri, C. R. Socool, and A. Pandy, "Alpha amylase production by A.oryzae employing solid state fermentation," Journal of Scientific and Industrial Research, vol. 66, pp. 621-626, 2007.

[9] S. Greene, "Extending integrated pest management to the golden apple snail: Examining a community centered approach in Northeast Thailand," Int. J. of Pest Management, vol. 54, pp. 95-102, 2008.

[10] M. S. Noor Hasyierah, A. Dachyar, M. D. M. Zulkali, P. Nilawati, and N. Rohaina, "Management of siput gondang emas in northen of Malaysia: Mini review," presented at the $3^{\text {rd }}$ International Conference on Biotechnology \& Food Science, APCBEE Procedia, 7-8 April, 2012, vol. 2, pp. 129-134.

[11] Z. Wang, J. Tan, L. Tan, J. Liu, and L. Zhong, "Control the egg hatching process of Pomacea canaliculata (Lamarck) b vjvvjn snail eggs: effect of water immersion and cannibalism," Wetlands, vol. 28 , pp. 544-549, 2008.

[12] D. C. Wu, J. Z. Yu, B. H. Chen, C. Y. Lin, and W. H. Ko, "Inhibition of egg hatching with apple wax solvent as a novel method for controlling golden apple snail (Pomacea canaliculata)," Crop Protection, vol. 24, pp. 483-486, 2005.

[13] M. Maketon, K. Suttichart et al., "Effective control of invasive apple snail (Pomacea canaliculata Lamarck) using Paecilomyces lilacinus (Thom) Samson," Malacologica, vol. 51, pp. 181-190, 2009.

[14] J. Ruiz, "Ultra structural analysis of the eggshell: Contribution of the individual calcified layers and the cuticle to hatchability and egg viability in broiler breeders," Br. Poult. Sci., vol. 41, pp. 584-592, 2000.

[15] R. G. Board and H. S. Tranter, The Microbiology of Eggs, 3rd ed, AVI Publishing Company, Inc, 1986.

[16] R. G. Board and N. A. Halls, "The cuticle: A barrier to liquid and particle penetration of the shell of the hen's egg," Br. Poult. Sci., vol. 14, pp. 69-97, 1973.

[17] M. T. Hincke, O. Weelman-Labadie, M. D. McKee, J. Gautron, Y. Nys, and K. Mann, Biosynthesis and Structural Assembly of Eggshell Components. In Egg Bioscience and Biotechnology, Wiley, 2008, pp. $97-128$.

[18] G. Whittow, Sturkie's Avian Physiology, $5^{\text {th }}$ ed, San Diego: Academic, 2000.

[19] N. H. M. Salleh, D. Arbain, and M. Z. M. Daud, "Preparation and thermal protease stability of biopesticide to control the Pomacea canaliculta's eggs," Journal of Life Science and Technologies, vol. 2, pp. 123-126, 2013.
[20] N. H. Mohd Salleh, D. Arbain, M. Z. M. Daud, and Z. A. Ahmad, "Protease-based biopesticide for disruption of Pomacea canaliculata eggs," presented at International Conference of Engineering and Management, organized by University Malaysia Perlis, Malaysia, 25-26 January, 2014

[21] A. O. Meyer-Willere and A. Santos-Soto, "Temperature and light intensity affecting egg production and growth performance of the Apple snail Pomacea patula (Baker 1922)," Advances en Investigacion Agropecuaria, vol. 10, pp. 41-58, 2006.

[22] Y. Liang, L. Pan, and Y. Lin, "Analysis of extracellular proteins of Aspergillus oryzae grown on soy sauce koji," Biosci. Biotechnol. Biochem, vol. 73, pp. 192-195, 2009.

[23] Kumar and R. Vats, "Protease production by Bacillus subtilis immobilized on different matrices," New York Science Journal, vol. 3 pp. 20-23, 2010

[24] V. Dipak and Y. I. Shethna, "Enhanced growth, sporulation and toxin production by Bacillus thringiensis subsp. kurstaki in oil seed meal extract media containing cysteine," World Journal of Microbiology \& Biotechnology, vol. 15, pp. 747-749, 1999.

[25] K. R. Sugumaran, V. Ponnusami, D. Gowdhaman, V. Gunasekar, and S. N. Srivastava, "Thermo stable alkaline protease production from Bacillus thuringiensis MTCC 1953: Optimization and kinetic studies," International Journal of ChemTech Research, vol. 4, pp. 198-202, 2012.

[26] O. P. Ward, W. M. Qin, J. Dhanjoon, J. Ye, and A. Singh, "Physiology and biotechnology of Aspergillus," Adv. Appl. Microbiol., vol. 58, pp. $1-55,2006$.

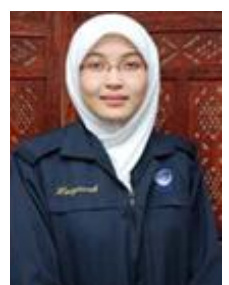

Noor Hasyierah Mohd Salleh was born in Kedah, Malaysia. She received her bachelor degree (B. Eng) in bioprocess engineering from the Universiti of National Malaysia (UKM), Kuala Lumpur, Malaysia in 2004 and obtained her master degree in bioprocess engine. She works at Universiti Malaysia Perlis (UniMAP), Malaysia since 2006. Her current interests are on synthesizing the mesoporous material from lignocellulosic biomass and the application of enzyme or biomaterial as a biopesticide from University Malaysia Perlis in 2012.

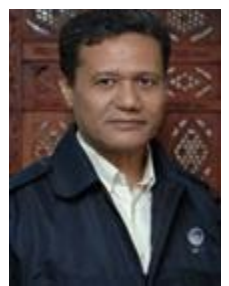

Dachyar Arbain was born in Bukit Tinggi, Indonesia. $\mathrm{He}$ received his $\mathrm{PhD}$. degree from the Centre for Biotechnology, Imperial College, Science of Technology and Medicine, Universiti of London UK in 1992.

$\mathrm{He}$ is now working as an assoc. professor at Universiti Malaysia Perlis (UniMAP), Malaysia since 2008. His current research interests are in the development of biosensor for various applications, herbal studies, nanomaterials, biomass conversion, upstream and downstream processing. 